\title{
Cellular development of the germinal epithelium during the gametogenic cycle of the golden mussel Limnoperna fortunei (Bivalvia: Mytilidae)
}

Claudenice Dei Tos ${ }^{1}$, Irani Quagio-Grassiotto ${ }^{2,3} \&$ Talita Sarah Mazzoni ${ }^{4}$

1. Biology Department, Center for Research in Limnology, Ichthyology and Aquaculture-Nupélia, State University of Maringá - UEM, CEP 87020-900, Av. Colombo, 5.790, Bloco H90, Sala 7B, Jd. Universitário, Maringá, PR, Brazil; claudenice@nupelia.uem.br

2. Morphology Department, Botucatu Biosciences Institute, State University of São Paulo - UNESP, CEP 18618-970, Rubião Junior District, s/n - Postal Box 510, Botucatu, SP, Brazil; iraniqg@ibb.unesp.br

3. Aquaculture Center of Unesp - CAUNESP, Jaboticabal, SP, Brazil.

4. Morphology Department, Botucatu Biosciences Institute, State University of São Paulo - UNESP, CEP 18618-970, Rubião Junior District, s/n - Postal Box 510, Botucatu, SP, Brazil; talitasarah@yahoo.com.br

\author{
Received 21-IV-2015. C Corrected 18-X-2015. Accepted 13-XI-2015.
}

\begin{abstract}
The golden mussel Limnoperna fortunei is an invasive species that has quickly dispersed and colonized several potential different habitats distributed all over the world, causing environmental and economic impacts. Thus, in order to contribute to a better understanding of the reproductive aspects of $L$. fortunei, we described the cellular dynamic of the male and female germinal epithelium during the annual reproductive life history of this species, with the use of high resolution histology. An approximate of 1200 specimens of $L$. fortunei were sampled periodically on the upper Paraná River floodplain (Brazil), from March 2010 to December 2012. Based on the activity of the germinal epithelium and consequent germ cell development, this study has resulted in the recognition of the following reproductive phases: Developing, Spawning Capable, Regressing and Regenerating. In the characterization of these phases, the following germ cells were described for males: spermatogonia, primary and secondary spermatocytes, spermatids and spermatozoa. Cell nests, oogonia, early prophase oocytes, previtellogenic oocytes and vitellogenic oocytes (early vitellogenic oocytes, middle vitellogenic oocytes and full-grown oocytes) were described for females. The morphological data and reproductive parameters obtained, showed the value of the cellular dynamics of the germinal epithelium, for the understanding of the cyclic gonadal events during the adult reproductive life of the mollusk in general. These results on the gametogenesis of this invasive species may be a fundamental tool for the development of control strategies and programs implementation, to reduce their proliferation and impacts in natural local environments. Rev. Biol. Trop. 64 (2): 521-536. Epub 2016 June 01.
\end{abstract}

Key words: Bivalvia, Mytilidae, oogenesis, spermatogenesis, ovary, testis, Limnoperna fortunei.

The golden mussel Limnoperna fortunei (Dunker, 1857) is a medium-sized bivalve mollusk belonging to the family Mytilidae (Darrigran \& Damborenea, 2006). Mytilidae is a family of small to large saltwater mussels (Soot-Ryen, 1955). Some of these species are edible and have high commercial value. However, L. fortunei is the only freshwater representative of Mytilidae (Darrigran \& Damborenea, 2006). It is recognized as a successful invader of aquatic environments in Asia, South
America and North America. An extensive revision was recently made by several authors about the biology, distribution, reproduction, ecology and other aspects of the life history of the golden mussel (Boltovskoy et al., 2015 for review). Special attention has been paid to its environmental impact (Darrigran, Penchaszadeh, \& Damborenea, 2000; Darrigran, 2002; Brugnoli, Clemente, Boccardi, Borthagaray, \& Scarabino, 2005; Boltovskoy, Sylvester, Otaegui, Leites, \& Cataldo, 2009; Santos et 
al., 2012; Boltovskoy \& Correa, 2015). L. fortunei is native to the rivers of China and Southeast Asia. However, this mollusk has been expanding its distribution into various parts of the world, as a consequence of increasing international trade and the great flow of vessels (Campos et al., 2014). Associated with this information, L. fortunei is capable of surviving fully in saline waters, lakes, humid areas and other water courses (Campos et al., 2014), showing various important features of a successful invader, such as a cycle of short duration, capacity of rapid growth and high fertility, in addition to wide physiological tolerance to several abiotic factors (Morton, 1977; Oliveira, Calheiros, Jacobi, \& Hamilton, 2011; Campos et al., 2014). Therefore, this species has great potential for establishing itself on all continents, since any environmentally suitable area can become a potential habitat (Campos et al., 2014).

Limnoperna fortunei is a filter-feeding (Morton, 1973) opportunist with a short life span (lives on average three years) and reaches between 3 and $4 \mathrm{~cm}$ when adult (Darrigran \& Damborenea, 2006; Campos et al., 2014). It is also gonochoric with external fertilization, and rare hermaphroditism has been recorded (Darrigran, Damborenea, \& Penchaszadeh, 1998; Darrigran, Damborenea, Penchaszadeh, \& Taraborelli, 2003; Callil, Gomes, \& Soares, 2012). It has gonads that develop inside the visceral mass and the pallial tissue (Morton, 1982; Darrigran \& Damborenea, 2006), and a high reproductive potential (Morton, 1977).

Several environmental and economic impacts are caused by Limnoperna fortunei, as recorded by Darrigran (2002), Takeda, Fujita and Fontes-Junior (2007), Santos et al. (2012) and Oliveira, Ayroza, Castellani, Campos and Mansur (2014). The control and management of the species depends on knowledge of its reproductive aspects. Thus, the reproductive cycle phases and period of spawning events of $L$. fortunei have been the focus of several studies (Morton, 1982; Darrigran, Penchaszadeh, \& Damborenea, 1999; Darrigran et al., 2003;
Damborenea \& Penchaszadeh, 2006; Callil, Gomes, \& Soares, 2012).

The gametogenic cycle of Limnoperna fortunei is regulated by environmental factors, especially temperature (Morton, 1982; Darrigran, Penchaszadeh, \& Damborenea, 1999; Darrigran et al., 2003). Gonadal development, changes in the germinal epithelium and the duration of each reproductive cycle vary according to climatic conditions. In subtropical regions, there is usually no definite and synchronic sequence of the gonadal development stages during the reproductive cycle. As a result, there may be continuous production of gametes, accompanied by numerous spawning events throughout the year (Darrigran \& Damborenea, 2006). Thus, in order to contribute to a better understanding of the reproduction of L. fortunei, we described the gonadal organization and the cellular dynamic of the male and female germinal epithelium during each reproductive cycle over its life history, using high resolution histology associated with quantitative data.

\section{MATERIALS AND METHODS}

Sampling area: A total of 1228 specimens of the golden mussel Limnoperna fortunei were collected quarterly from March 2010 to December 2012 (during autumn, winter, spring and summer) in rivers of the upper Paraná River floodplain, Brazil (22045'39.96" S - 53ำ'7.44" W), being 315 individuals (138 males, 177 females) in 2010, 465 individuals (186 males and 279 females) in 2011 and 448 individuals (195 males and 253 females) in 2012. A subsample of 688 reproductively active individuals (52 females +90 males in winter; 23 females +45 males in autumn; 83 females + 99 males in spring; and 97 females +199 males in summer) varying from 1.0 to $3.86 \mathrm{~cm}$ valves length, were measured with a pachymeter, and was used to classify the reproductive phases. Sampling was carried out using a Petersen grab (modified for benthic sampling) or manually (when they were on submerged branches or on aquatic macrophytes). The valves of the 
golden mussel were separated, opened and the visceral mass was removed by cutting the adductor and retractor muscles. The visceral mass of these 688 individuals was removed and fixed by immersion in Bouin's fluid. A sample of gonads from males and females was photographed using a digital camera (Fujifilm HD 14MP Finepix S2800) and processed for light microscopy.

Histology and light microscopy (LM): The visceral mass fixed in Bouin's fluid was dehydrated in ethanol and embedded in historesin (Leica historesin). Serial sections (3 $\mu \mathrm{m}$ thick) were stained with Periodic-AcidSchiff's (PAS)/Haematoxylin/Metanil Yellow (Quintero-Hunter, Grier, \& Muscato, 1991) and $0.5 \%$ Toluidine Blue (Vidal, 1987; Mello \& Vidal, 1980). These sections were stained using the Reticulin Method, which enhances basement membranes, and resulted in a black hue of reticulin fibers (modified from Puchtler \& Waldrop, 1978; Vidal, 1988). Gonad sections were evaluated using a computerized image analyzer (Leica LAS Interactive Measurements).

Alterations of the germinal epithelium during the adult reproductive life history: The reproductive cycle of the golden mussel was classified in phases based on the alterations of the germinal epithelium (Boltovskoy et al., 2015) considering the stages (and steps) of the germ cell differentiation, predominant type of germ cell, repletion of gonadal tubules, and the presence of mature germ cells in the gonoduct. Therefore, reproductive phases of males were recognized according to the presence of spermatogonia, primary and secondary spermatocytes, spermatids and spermatozoa. As regards females, the presence of oogonial proliferation, early prophase oocytes, previtellogenic oocytes, vitellogenic (early vitellogenic oocytes, middle vitellogenic oocytes) and fullgrown oocytes, empty ovarian tubules and atretic oocytes were considered.

Quantitative analysis: The frequency of each reproductive phase throughout the seasons of the year between females and males was calculated from the number of adults analyzed $(\mathrm{n}=688)$.

The size of the vitellogenenic oocytes was measured using a computerized image analyzer (Leica LAS Interactive Measurements), in order to check the variation between the minimum and maximum diameter of these oocytes.

\section{RESULTS}

Gonadal morphology: The gonadal tissue from the golden mussel L. fortunei was located throughout the visceral mass and was dispersed by the pallial tissue. The testis (Fig. 1 A, Fig. 1B) consisted of a white tissue, while the ovary (Fig. 2 A, Fig, 2B, Fig. 2C) was formed by a tissue with orange clusters, the oocytes.

In serial histological sections (longitudinal and transversal), the testis (Fig. 1C, Fig. 1D, Fig. 1E) and ovary (Fig. 2D) of the golden mussel L. fortunei showed a system of branched tubules (Fig. 2E, Fig. 2F) with an arborescent aspect that opened in a ciliated gonoduct (Fig. 2G, Fig. 2H, Fig. 2I). With gonadal development, the gonadal tubules increased in number and protruded into the pallial tissue. The tubules in the testis and ovary were delineated by an epithelium that contained somatic and germ cells. The germinal epithelium rested on the basement membrane (Fig. 1F, Fig. 1G, Fig. $1 \mathrm{H}$ and Fig. 2J, Fig. 2K, Fig. 2L). Developing male and female germ cells protruded into the lumen of testicular and ovarian tubules.

Spermatogenesis: Male germ cells in distinct steps of spermatogenesis were found in the testis of the golden mussel L. fortunei throughout the reproductive cycle (Fig. 3A, Fig. 3B, Fig. 3C, Fig. 3D, Fig. 3E, Fig. 3F, Fig. $3 \mathrm{G}$, Fig. 3H, Fig. 3I). Among the germ cells were the Sertoli cells (Fig. 3I). They rested on the basement membrane of the germinal epithelium that lined the tubular testis and extended toward the lumen, coming into contact with spermatogonia, spermatocytes and spermatids. With the proliferation of the germ and somatic cells, the testicular tubules lengthened and, 

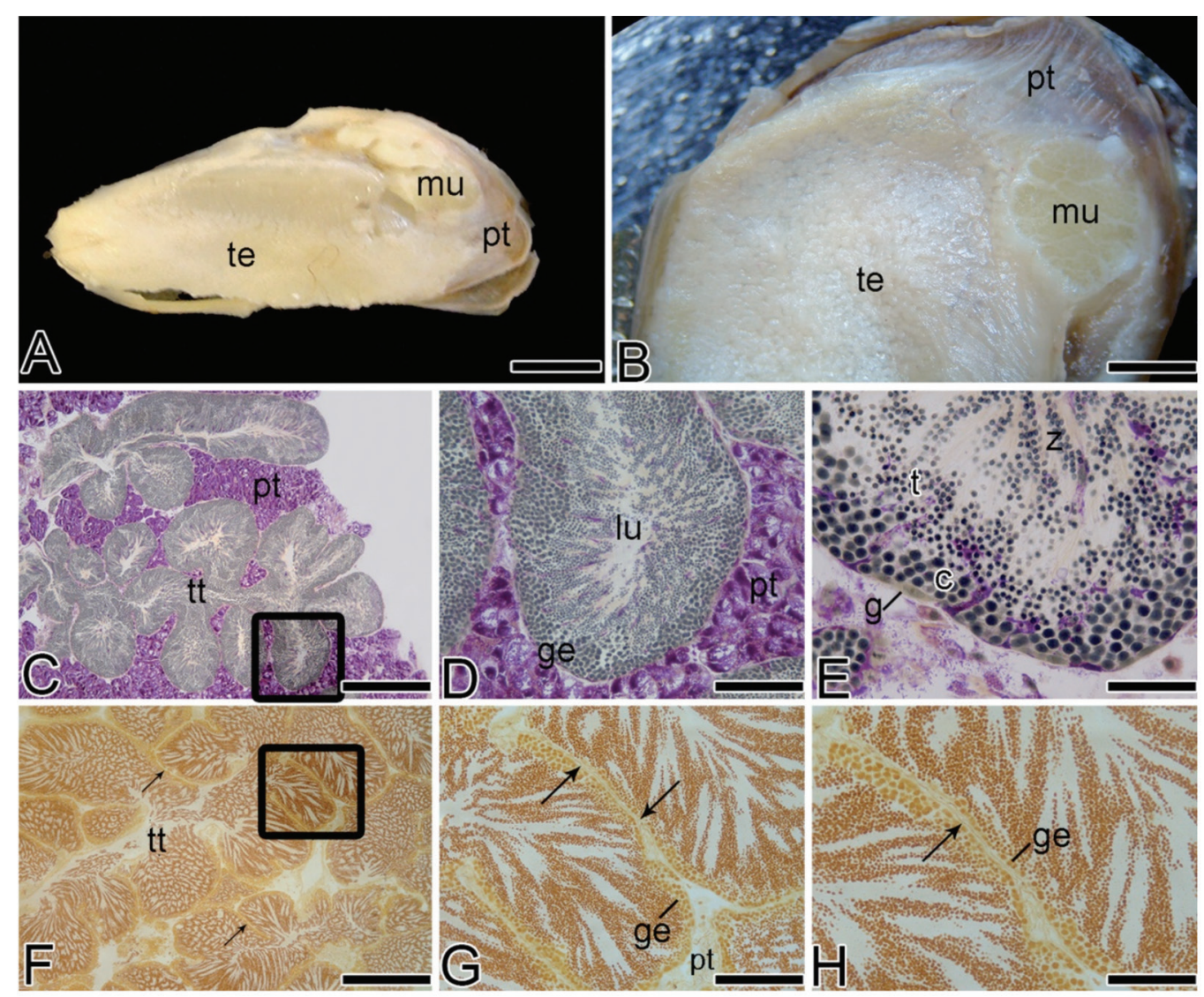

Fig. 1. Macroscopic and microscopic features of a testis of the golden mussel L. fortunei. (A) Macroscopic general view of a testis in spawning capable phase. (B) Partial view of a testis in the spawning capable phase. (C) Photomicrograph of a histological longitudinal section of testicular tubules and pallial tissue. Note the anastomosed testicular tubules form sinuous channels. (D) Detail of a testicular tubule showing a radial pattern of germ cell disposition, lumen, germinal epithelium and pallial tissue. (E) Note from the periphery to the lumen of the tubules: spermatogonia, spermatocytes, spermatids and spermatozoa. (C-E) Stained with Periodic-acid Schiff (PAS)/Haematoxylin/MetanilYellow. (F) General view of testicular tubules and basement membrane (arrow). (G) Detail of testicular tubules and very fine, delicate basement membrane (arrow) in brownish black stain using Reticulin method, germinal epithelium and pallial tissue. (H) Detail of basement membrane (arrow) and germinal epithelium. c, spermatocytes; g, spermatogonia; ge, germinal epithelium; lu, lumen; mu, muscle; pt, pallial tissue; t, spermatids; te, testis; tt, testicular tubules; z, spermatozoa. Scale bars: $\mathbf{A}=4 \mathrm{~mm} ; \mathbf{B}=2 \mathrm{~mm} ; \mathbf{C}=200 \mu \mathrm{m} ; \mathbf{D}=50$ $\mu \mathrm{m} ; \mathbf{E}=20 \mu \mathrm{m} ; \mathbf{F}=200 \mu \mathrm{m} ; \mathbf{G}=100 \mu \mathrm{m} ; \mathbf{H}=30 \mu \mathrm{m}$.

consequently, the whole testis enlarged. As regards spermatogenesis, the morphological characterization of the male germ cells that were present in the testis of $L$. fortunei was summarized in Table 1.

Oogenesis: Female germ cells in distinct steps of oogenesis were found in the ovary of the golden mussel Limnoperna fortunei throughout the reproductive cycle (Fig. 4A, Fig. 4B, Fig. 4C, Fig. 4D, Fig. 4E, Fig. 4F, Fig. 4G, Fig. 4H, Fig. 4I). In the germinal epithelium that lined the ovarian tubules, oogonial proliferation formed clusters of germ cells (nests) that projected into the ovarian lumen (Fig. 4A, Fig. 4B, Fig. 4C, Fig. 4D). In the nests, oogonia entered into meiosis, and gave rise to oocytes (Fig. 4E, Fig. 4F). Concomitant 


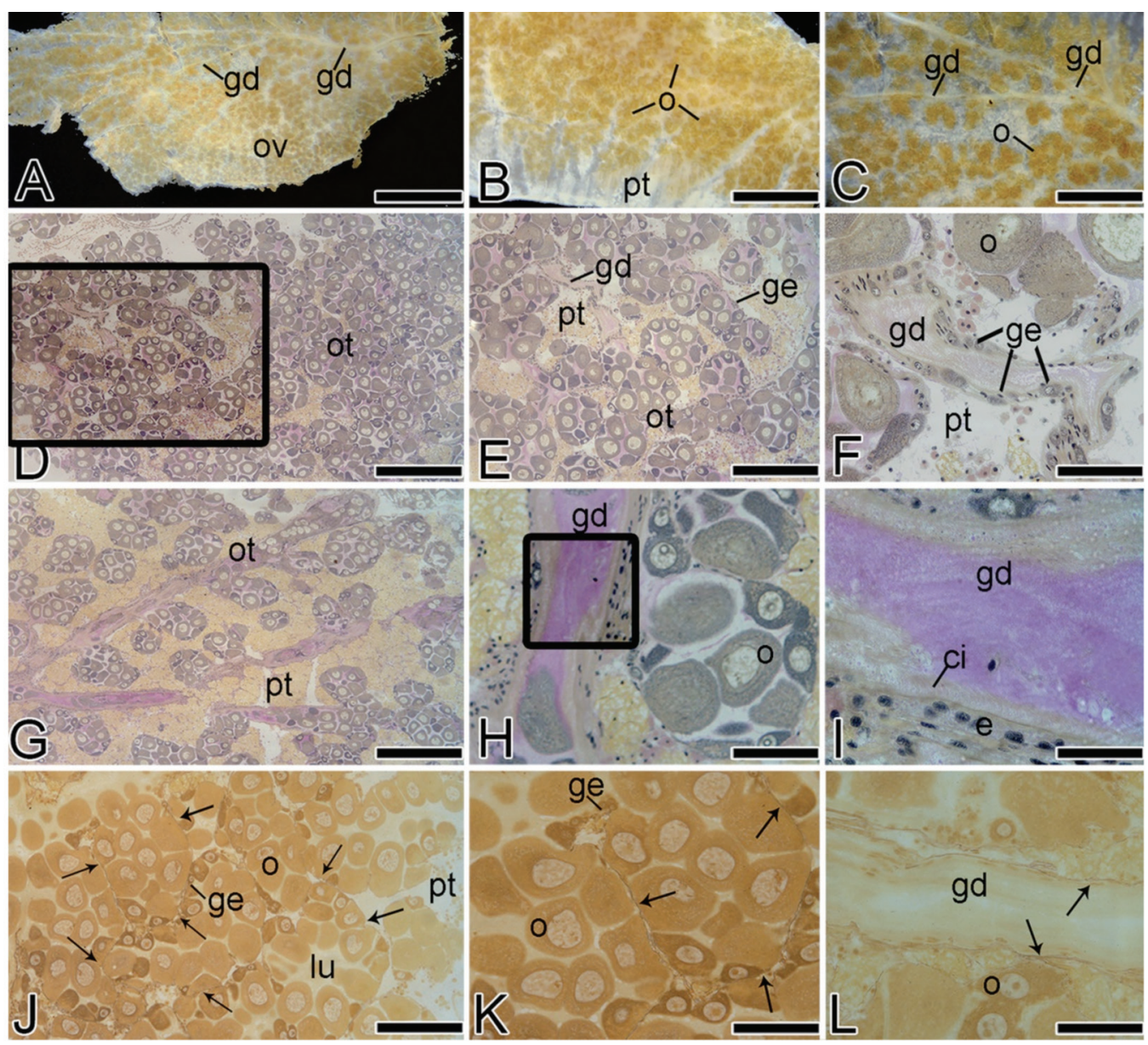

Fig. 2. Macroscopic features of an ovary of the golden mussel L. fortunei. (A-C) View of an ovary in spawning capable phase and visible oocytes, pallial tissue and gonadal duct. (D-I) Microscopic features of a longitudinal ovary section of the golden mussel (Periodic-acid Schiff (PAS)/Haematoxylin/Metanil Yellow). (D-E) General view of an ovary in spawning capable phase showing the organization of an ovarian tubule, gonadal duct, pallial tissue and germinal epithelium. (F) Detail of a gonadal duct with germinal epithelium, pallial tissue and oocyte. (G) General view of a longitudinal section of an ovary. (H-I) Detail of gonadal duct showing cilia and epithelium. (J-L) Photomicrograph of a longitudinal section of an ovary in spawning capable phase stained using the Reticulin Method. (J) General view of an ovary showing the basement membrane (arrows) and ovarian tubules stained in brownish black, germinal epithelium, oocyte, lumen and pallial tissue. (K) Detail of the basement membrane (arrows) delimitating the ovarian tubules full of oocytes. (L) Detail of a gonadal duct with the ciliated epithelium resting on the basement membrane (arrows). ci, cilia; e, epithelium; gd, gonadal duct; ge, germinal epithelium; lu, lumen; o, oocytes; ot, ovarian tubule; ov, ovary; pt, pallial tissue. Scale bars: $\mathbf{A}=16 \mathrm{~mm} ; \mathbf{B}=8 \mathrm{~mm} ; \mathbf{C}=10 \mathrm{~mm}$; $\mathbf{D}=500 \mu \mathrm{m} ; \mathbf{E}, \mathbf{F}, \mathbf{G}=200 \mu \mathrm{m} ; \mathbf{H}, \mathbf{I}, \mathbf{J}=100 \mu \mathrm{m} ; \mathbf{K}=20 \mu \mathrm{m} ; \mathbf{L}=50 \mu \mathrm{m}$.

with oogonial proliferation, somatic epithelial cells also proliferated. Resulting from both germ and somatic cell proliferation, the epithelium and the ovarian tubules lengthened. As a consequence, the whole ovary enlarged. During their entire development, the oocytes remained attached to a short extension of the epithelium of the ovarian tubules. As the oocytes increased, they protruded into the tubular lumen and, consequently, the diameter of the tubules also enlarges. Early vitellogenic oocytes presented a minimum diameter of $40.16 \mu \mathrm{m}$ (Fig. $4 \mathrm{~F}$ ) and with the progression of vitellogenesis, the oocytes reached a maximum 

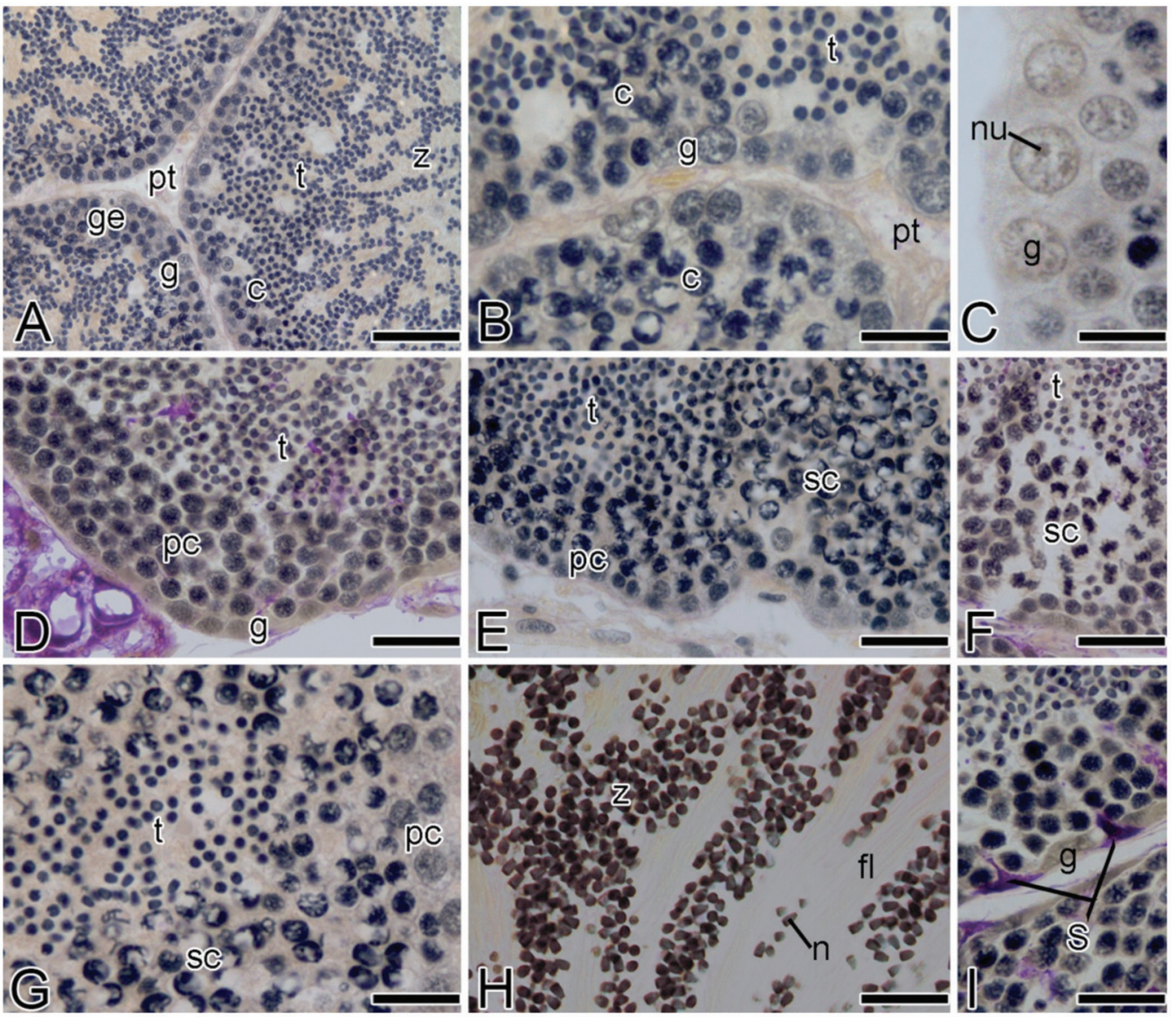

Fig. 3. Photomicrograph illustrating part of the testicular tubules of the golden mussel L. fortunei (Light Microscopy, Periodic-acid Schiff (PAS)/Haematoxylin/Metanil Yellow). (A) General view of part of the testicular tubules, pallial tissue, germinal epithelium, spermatogonia, spermatocytes, spermatids and spermatozoa. (B) Detail of the testis, showing the germinal epithelium with spermatogonia, spermatocytes, spermatids, spermatozoa and pallial tissue. (C) Detail of spermatogonia and nucleolus. (D) View of part of the testicular tubules, showing spermatogonia, primary spermatocytes and spermatids. (E) Detail of the testicular tubules with primary spermatocytes, secondary spermatocytes in pachytene and spermatids. (F) Secondary spermatocytes in metaphase and spermatids. (G) Primary spermatocytes, secondary spermatocytes and spermatids. (H) Detail of spermatozoa, nucleus and flagellum. (I) Detail of the germinal epithelium showing spermatogonia and Sertoli cells stained in magenta. c, spermatocytes; ge, germinal epithelium; fl, flagellum; g, spermatogonia; n, nucleus; nu, nucleolus; pc, primary spermatocytes; pt, pallial tissue; S, Sertoli cells; sc, secondary spermatocytes; t, spermatids; z, spermatozoa. Scale bars: $\mathbf{A}=30 \mu \mathrm{m} ; \mathbf{B}, \mathbf{D}, \mathbf{E}, \mathbf{F}, \mathbf{G}, \mathbf{H}, \mathbf{I}=10 \mu \mathrm{m} ; \mathbf{C}=5 \mu \mathrm{m}$.

diameter of $142.13 \mu \mathrm{m}$ (Fig. 4I), when they were called full-grown oocytes (number of oocytes measured $=83$ ). Oogonial proliferation and progressive morphological changes in the ooplasm of the oocytes were used to classify oogenesis in distinct stages that included oogonial proliferation, chromatin nucleolus, primary growth and secondary growth (vitellogenesis).
As regards the oogenesis stages, the morphological characterization of the female germ cells that were present in the ovary of $L$. fortunei was summarized in Table 2.

Reproductive phases: During the adult reproductive life history of males or females of L. fortunei, the renewal of the germ cells, 
TABLE 1

Morphology of male germ cells of the golden mussel L. fortunei

Germ cells

Spermatogonia

Primary spermatocytes

Secondary spermatocytes

Spermatids

Spermatozoa

\section{Diagnosis}

Spermatogonia are the largest cells of the male germinal lineage. They are located in the epithelium of the testicular tubules. They have a large nucleus, spherical to oval in shape and their cytoplasm is abundant, granular and acidophilic. The nucleus is basophilic, contains delicate granular chromatin and one, two or three nucleoli that are more intensely basophilic (Fig. 3A, Fig 3B, Fig. 3C). Spermatogonia proliferate and enter into meiosis, giving rise to primary spermatocytes.

Primary spermatocytes are more numerous and smaller than spermatogonia and usually occur in groups that protrude into the luminal compartment of the testis. They are spherical cells with a basophilic nucleus with condensed characteristic chromatin (Fig. 3D, Fig. 3E). They are smaller than secondary spermatogonia. Primary spermatocytes complete the first divisions of the meiosis that produces secondary spermatocytes.

Secondary spermatocytes are smaller than primary spermatocytes. They are spherical, with hyaline cytoplasm. In these spermatocytes, the chromatin in the nucleus of the pachytene oocytes, even more condensed, takes the shape of an umbrella (Fig. 3E, Fig. 3F). Considering a centripetal disposition, they are nearer to the luminal center. They are seen less frequently than primary spermatocytes and have a very short lifespan, divide rapidly after a short interphase between the two meiotic divisions, and produce two spherical spermatids.

Spermatids are smaller than secondary spermatocytes. They are spherical cells with intensely condensed nuclear chromatin (Fig. 3G). By a process of citodifferentiation called spermiogenesis, they transform into spermatozoa.

Spermatozoa are the smallest cells of the germinal lineage. They have a strongly bullet-shaped basophilic nucleus (Fig. 3H). Spermatozoa accumulate in the lumen of the testis in radial disposition. When released they accumulate in the lumen of the testicular duct (Fig. 3G, Fig. 3H, Fig. 3I).

TABLE 2

Stages of oogenesis and morphological characteristics of the female germ cells in the golden mussel L. fortunei

\begin{tabular}{|c|c|c|}
\hline Stages & Steps & Diagnosis \\
\hline $\begin{array}{l}\text { Oogonial } \\
\text { proliferation stage }\end{array}$ & Cell nests & $\begin{array}{l}\text { Oogonial proliferation results in the formation of germ cell nests in the } \\
\text { epithelium that lines the ovarian tubules. In the cell nests, oogonia are } \\
\text { distinguished by having slightly basophilic spherical to oval nuclei, an evident } \\
\text { nucleolus and scarce ooplasm (Fig. 4A, Fig 4B, Fig. 4C). }\end{array}$ \\
\hline $\begin{array}{l}\text { Early prophasic } \\
\text { stage }(\mathrm{CN})\end{array}$ & $\begin{array}{l}\text { Leptotene, zygotene, } \\
\text { pachytene }\end{array}$ & $\begin{array}{l}\text { Oogonia enter into meiosis, giving rise to oocytes. The early prophasic } \\
\text { oocytes have a basophilic nucleus with a spherical or slightly oval-shaped and } \\
\text { scarce ooplasm. The early prophase stage comprises the leptotene, zygotene } \\
\text { and pachytene steps of the meiotic prophase I, which are recognized by their } \\
\text { distinct chromatin pattern (Fig. } 4 \mathrm{D} \text {, Fig. } 4 \mathrm{E} \text {, Fig } 4 \mathrm{~F} \text { ). It ends with the arrest of } \\
\text { the meiosis division at the diplotene step. }\end{array}$ \\
\hline \multirow[t]{2}{*}{$\begin{array}{l}\text { Previtellogenic } \\
\text { stage (PG) }\end{array}$} & & $\begin{array}{l}\text { The oocytes are larger relative to the previous stage. Their nucleus is clear, } \\
\text { spherical to slightly oval in shape, has one, sometimes two nucleoli, and the } \\
\text { ooplasm is strongly basophilic. With the increase of these oocytes, ooplasm } \\
\text { becomes progressively less basophilic. Previtellogenic oocytes are found in } \\
\text { the epithelium of the ovarian tubules (Fig. 4D, Fig. 4F). }\end{array}$ \\
\hline & $\begin{array}{l}\text { Early vitellogenic } \\
\text { oocytes (SGe) }\end{array}$ & $\begin{array}{l}\text { In this step, the oocytes are larger than those from previous steps. Their } \\
\text { nucleus is spherical to slightly oval in shape and has evident nucleoli. } \\
\text { Their cytoplasm gradually loses basophily and becomes acidophilic due } \\
\text { to the beginning of yolk globule formation. These cells are attached to the } \\
\text { epithelium of the ovarian tubules in a stalk (Fig. 4A, Fig. 4F, Fig. 4G.). }\end{array}$ \\
\hline
\end{tabular}


CUADRO 2 (Continuación) / TABLE 2 (Continued)

\begin{tabular}{lll}
\multicolumn{1}{c}{ Stages } & \multicolumn{1}{c}{ Steps } \\
Vitellogenic stage & $\begin{array}{l}\text { Middle vitellogenic } \\
\text { oocytes (SGl) }\end{array}$ & $\begin{array}{l}\text { Compared to the preceding step, the oocytes are larger and have more } \\
\text { acidophilic ooplasm with a large amount of yolk globules. They have a large } \\
\text { spherical to oval shape, a spherical nucleus with one or two nucleoli evident } \\
\text { and remain connected to the epithelium of the ovarian tubules (Fig. } 4 \mathrm{H}) .\end{array}$ \\
& $\begin{array}{l}\text { Full-grown oocytes } \\
\text { (SGfg) }\end{array}$ & $\begin{array}{l}\text { These oocytes are more voluminous cells, having a spherical to oval or } \\
\text { slightly irregular shape. Their nucleus is large, central or eccentric, has one } \\
\text { or more nucleoli and displays irregular outlines. Their ooplasm is acidophilic } \\
\text { and filled with abundant yolk globules (Fig 4I). When ready for spawning, } \\
\text { they detach from the epithelium tubules, enter the ovarian lumen and move } \\
\text { progressively toward the gonoduct. }\end{array}$ \\
\hline
\end{tabular}
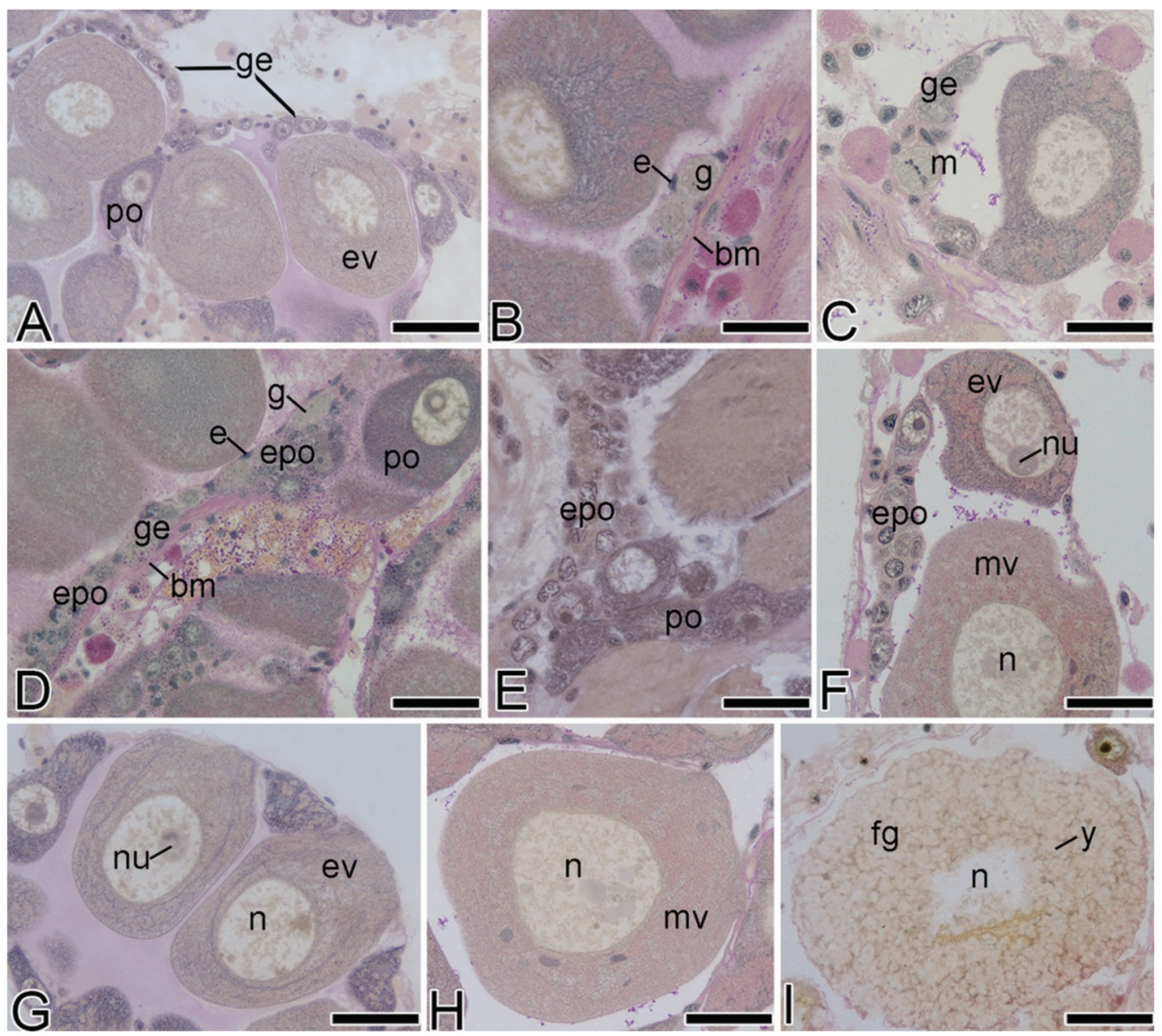

Fig. 4. Partial view of longitudinal sections of an ovary of the golden mussel L. fortunei in different phases of germ cell development (Light Microscopy, Periodic-acid Schiff(PAS)/Hematoxylin/Metanil Yellow). (A) General view of the germinal epithelium composed of cell nests, previtellogenic oocytes and early vitellogenic oocytes. (B) Detail of cell nests composed of oogonia, which rest on the basement membrane and epithelial cells. (C) Detail of nest showing oogonium in metaphase and germinal epithelium. (D) General view of a nest which rests on the basement membrane, composed of oogonium, epithelial cells, early prophasic oocytes and vitellogenic oocytes. (E) General view of cell nest with early prophasic oocytes and previtellogenic oocytes stages. (F) Detail of cell nests showing early prophasic oocytes, early vitellogenic oocytes, nucleolus, nucleus and middle vitellogenic oocytes. (G) Partial view of an ovarian tubule with early vitellogenic oocytes, 
nucleus and nucleolus. (H) Detail showing middle vitellogenic oocytes attached to the germinal epithelium. (I) General view of full-grown oocytes, nucleus and yolked globules. bm, basement membrane; e, epithelial cells; epo, early prophasic oocytes; ev, early vitellogenic oocytes; fg, full-grown oocytes; g, oogonia; ge, germinal epithelium; m, metaphase; mv, middle vitellogenic oocytes; n, nucleus; nu, nucleolus; po, previtellogenic oocytes; y, yolked globules. Scale bars: $\mathbf{A}=50 \mu \mathrm{m}$; $\mathbf{B}, \mathbf{C}, \mathbf{D}, \mathbf{E}, \mathbf{F}=20 \mu \mathrm{m} ; \mathbf{G}=50 \mu \mathrm{m} ; \mathbf{H}=40 \mu \mathrm{m} ; \mathbf{I}=60 \mu \mathrm{m}$.

TABLE 3

Characterization of the phases in the reproductive cycle of males of the golden mussel L. fortunei

\begin{tabular}{|c|c|}
\hline Phases / Males & Diagnosis \\
\hline $\begin{array}{l}\text { 1. Regenerating (sexually mature, } \\
\text { reproductively inactive) }\end{array}$ & $\begin{array}{l}\text { The testis tubules present spermatogonia, many primary and secondary } \\
\text { spermatocytes, and sometimes contain few spermatozoa in their lumen (Fig. } \\
\text { 5A, Fig. 5B, Fig. 5C). Some tubules are completely empty. }\end{array}$ \\
\hline $\begin{array}{l}\text { 2. Developing (testis beginning to grow } \\
\text { and develop, but they are not ready to } \\
\text { release sperm) }\end{array}$ & $\begin{array}{l}\text { The tubules increase in size relative to the regenerating phase. } \\
\text { Spermatogonia and primary and secondary spermatocytes are abundant. } \\
\text { Spermatids and spermatozoa can be observed in small amounts (Fig. 5D, Fig. } \\
\text { 5E). }\end{array}$ \\
\hline $\begin{array}{l}\text { 3. Sperm releasing capable (in this } \\
\text { phase of reproduction, they are } \\
\text { developmentally and physiologically } \\
\text { able to release sperm) }\end{array}$ & $\begin{array}{l}\text { The tubules reach their maximum size. The luminal compartment is filled by } \\
\text { a large amount of spermatozoa (Fig. 5G, Fig. 5H, Fig. 5I). Spermatogonia } \\
\text { and spermatocytes in small number are seen in the germinal epithelium. } \\
\text { Empty tubules are rare and indicate an active release of sperm. }\end{array}$ \\
\hline $\begin{array}{l}\text { 4. Regressing (cession of the release of } \\
\text { sperm) }\end{array}$ & $\begin{array}{l}\text { The tubules lose their shape, shrink, and a smaller number of residual sperm } \\
\text { can be found in their reduced lumen. Only small clusters of spermatogonia } \\
\text { remain in a disorganized epithelium. There are empty tubules that } \\
\text { consequently become small relative to the sperm releasing capable phase. } \\
\text { (Fig. 5J, Fig. 5K, Fig. 5L). }\end{array}$ \\
\hline
\end{tabular}

their differentiation, development, maturation and release resulted in gonadal alterations that characterized different phases over each reproductive cycle.

Thus, considering the types of germ cells, as well as their predominance in the gonad, four phases were described over the reproductive cycle of L. fortunei males: regenerating, developing, sperm releasing capable and regressing (Table 3; Fig. 5A, Fig. 5B, Fig. 5C, Fig. 5D, Fig. 5E, Fig. 5F, Fig. 5G, Fig. 5H, Fig. 5I, Fig. 5J, Fig. 5K, Fig. 5L).

As regards, the females and the types of germ cells, as well as their predominance in the gonad, four phases were described over the reproductive cycle of $L$. fortunei: regenerating, developing, spawning capable and regressing (Table 4; Fig. 6 A, Fig. 6B, Fig. 6C, Fig. 6D, Fig. 6E, Fig. 6F, Fig. 6G, Fig. 6H, Fig. 6I, Fig. 6J, Fig. 6K, Fig. 6L).

Reproductive parameters: The valve lengths of sexually active (mature) individuals varied from $1.72 \mathrm{~cm}$ to $3.72 \mathrm{~cm}(\mathrm{n}=255)$ and $1.01 \mathrm{~cm}$ to $3.86 \mathrm{~cm}(\mathrm{n}=433)$ for females and males, respectively. Parameters of immature individuals, i.e. with valves having a total length below $1.0 \mathrm{~cm}$ were not considered.

The frequency of individuals in different reproductive phases showed that the majority of females (36.54-86.96\%) and males (50.0$80.40 \%$ ) were in the development phase (Fig. 7). Females presenting full-grown oocytes, i.e. belonging to the spawning capable phase, were found only in summer (Fig. 7). In contrast, males in this same phase were found throughout the year (Fig. 7).

\section{DISCUSSION}

The serial longitudinal sections from the whole gonad of the adult male or female of $L$. fortunei showed that, in reproductively active individuals, the testis or ovaries are formed by a continuous system of branched tubules. The 

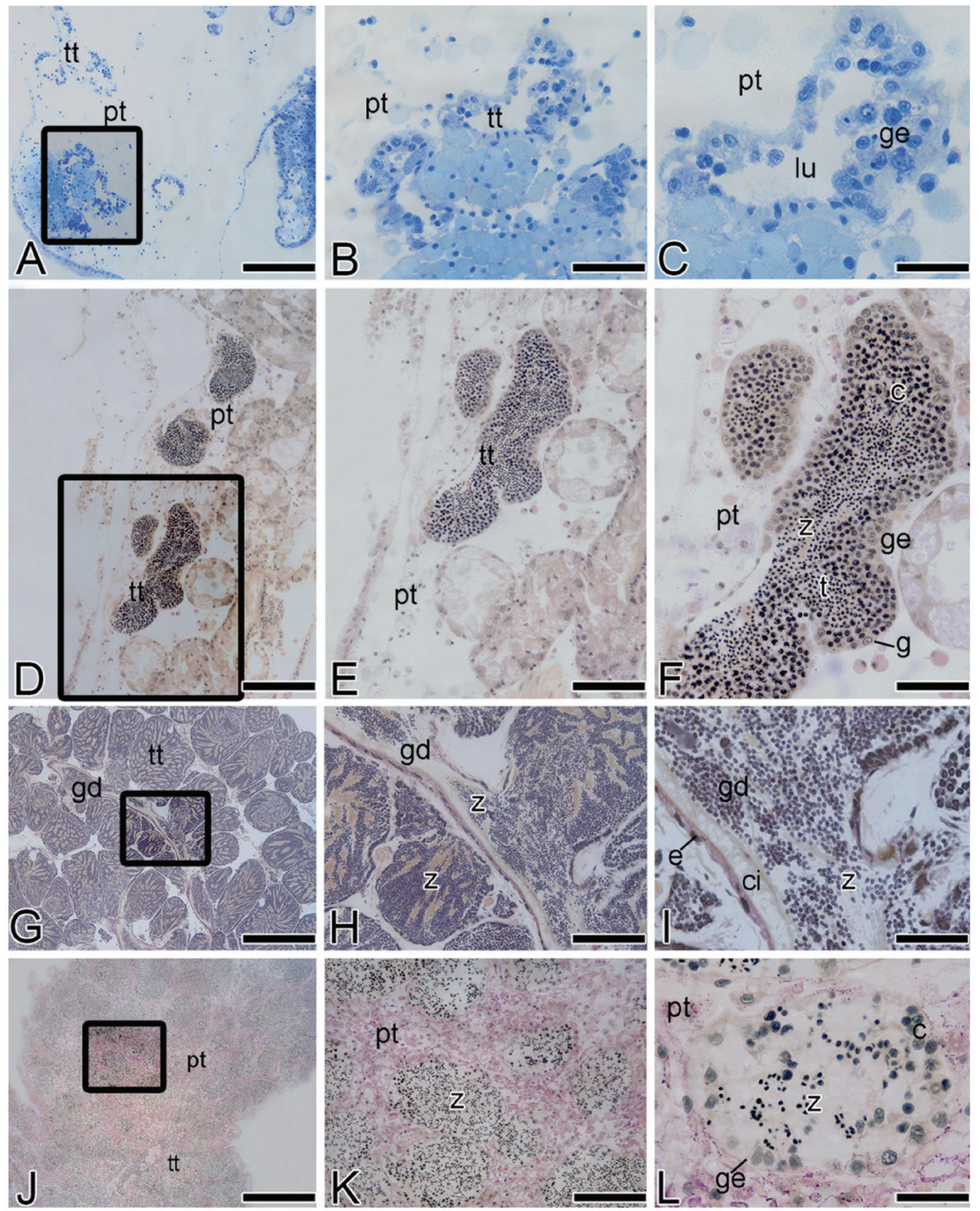

Fig. 5. Partial view of longitudinal sections of a testis of the golden mussel L. fortunei. (A-C) View of the regenerating phase of a testis, light microscopy, Toluidine Blue. (A-B) General view of the testicular tubules and pallial tissue. (C) Detail of a tubule showing germ cells, pallial tissue, lumen and epithelium germinal. (D-E) View of the testis in the developing phase, pallial tissue and testicular tubules. (F) Detail of tubule showing pallial tissue, germinal epithelium, spermatogonia, spermatocytes, spermatids and a small amount of spermatozoa. (G-H) General view of the testis in spawning capable phase showing gonadal duct, testicular tubules and spermatozoa. (I) Detail of the ciliated testicular gonoduct showing lumen full of spermatozoa, cilium, gonadal duct and epithelial cells. (J-K) General view of the testis in regressing testicular tubules, pallial tissue and spermatozoa. (L) Details of the testis in regressing testis tubules with some clusters of spermatocytes in the periphery of the tubule and spermatozoa in the lumen, pallial tissue and germinal epithelium. (D-L) Light Microscopy, Periodic-acid Schiff (PAS)/Haematoxylin/Metanil Yellow. c, spermatocytes; ci, cilia; e, epithelial cells; g, spermatogonia; gd, gonadal duct; ge, epithelium germinal; lu, lumen; pt, pallial tissue; tt, testicular tubules; t, spermatids; $\mathrm{z}$, spermatozoa. Scale bars: A, D, G=100 $\mu \mathrm{m} ; \mathbf{B}, \mathbf{E}, \mathbf{H}, \mathbf{K}=50 \mu \mathrm{m} ; \mathbf{C}, \mathbf{F}=20 \mu \mathrm{m} ; \mathbf{I}, \mathbf{L}=15 \mu \mathrm{m} ; \mathbf{J}=150 \mu \mathrm{m}$. 
TABLE 4

Characterization of the phases in the reproductive cycle of females of the golden mussel L. fortunei

Phases / Females

1. Regenerating (sexually mature, reproductively inactive)

2. Developing (ovary beginning to grow and develop)

3. Spawning capable (in this phase of reproduction, they are developmentally and physiologically able to spawn)

4. Regressing (cession of spawning)

\section{Diagnosis}

The ovarian tubules present a reduced lumen. Oogonial proliferation becomes evident with the formation of the germ cell nests. Oocytes are in the chromatin nucleolus and primary growth stages (one-nucleolus steps) (Fig. 6 A, Fig. 6B, Fig. $6 \mathrm{C})$

The size of the tubules increases relative to the regenerating phase. Tubules containing germ cell nests with proliferating oogonia and chromatin nucleolus oocytes occur. Oocytes in early primary growth, abundant late previtellogenic oocytes and early and middle vitellogenic oocytes are present (Fig. 6D, Fig. 6E, Fig. 6F).

The size of the tubules (in length and diameter) is larger than in the previous phase. Oocytes are in distinct steps of vitellogenesis. Previtellogenic oocytes and middle vitellogenic oocytes are present, but full-grown oocytes fill the lumen. The full-grown oocytes are rounded to elongated or irregular and their ooplasm is completely full of yolk (Fig. 6G, Fig. 6H, Fig. 6I). The nucleus (or germinal vesicle) is usually situated at the center of the oocyte. Few proliferating oogonia, oocytes in the chromatin nucleolus, primary growth stages, and empty tubules can be observed.

The ovarian tubules are smaller than in the previous phase. The tubules possess middle vitellogenic oocytes and full-grown oocytes. They became disorganized and the unovulated oocytes degenerate (Fig. 6J, Fig. 6K, Fig. 6L). Nests with oogonia and early prophase oocytes also occur. continuous system of tubules is confirmed by the reticulin stain that enhances the basement membrane components. The basement membrane is synthesized by the somatic cells from the germinal epithelium, as is usual in epitheliums (Alberts, Johnson, Lewis, Raff, Roberts, $\&$ Walter, 2008). Thus, the germinal epithelium rests upon a basement membrane that separates it from the pallial tissue. Recent studies by Franco, Heude-Berthelin, Goux, Sourdaine and Mathieu (2008), Franco et al. (2010) and Franco, Kellner, Goux, Mathieu and HeudeBerthelin (2011) also recognized that bivalve gonads are formed by a continuous system of branched tubules.

As seen in L. fortunei, except for the gonoduct, in both males and females, the epithelium, bordering the gonadal tubules, houses germ cells and is active in gamete production. Thus, the proliferation of the germ and epithelial cells is responsible for the increase in the number and length of the gonadal tubules throughout the reproductive cycle. Other reproductive characteristics of bivalves, including $L$. fortu$n e i$, are that in the female the oocytes protrude toward the ovarian lumen, are not surrounded by a layer of somatic cells and remain connected to the germinal epithelium throughout their development. This connection, referred to as a stalk, is broken when the mature oocytes are released into the luminal compartment of the ovary (Pipe, 1987; Shafee, 1989; Garton \& Haag, 1993; Darrigran \& Damborenea, 2006; Saucedo \& Southgate, 2008). Therefore, it is reasonable to assume that the nutrition of the oocytes occurs through the stalk.

In the mollusk, reproduction is a cyclical event during its life history. Thus, various scales (i.e. inactive, developing, maturing, mature, and spent) categorizing gonadal alterations throughout the reproductive cycle are reported in the bivalve literature (see Lubert, 1959; Shafee, 1989; Saucedo \& Southgate, 2008; Franco et al., 2011; Boltovskoy et al., 2015 for review). Despite reporting the same event, reproductive cycle scales vary depending 

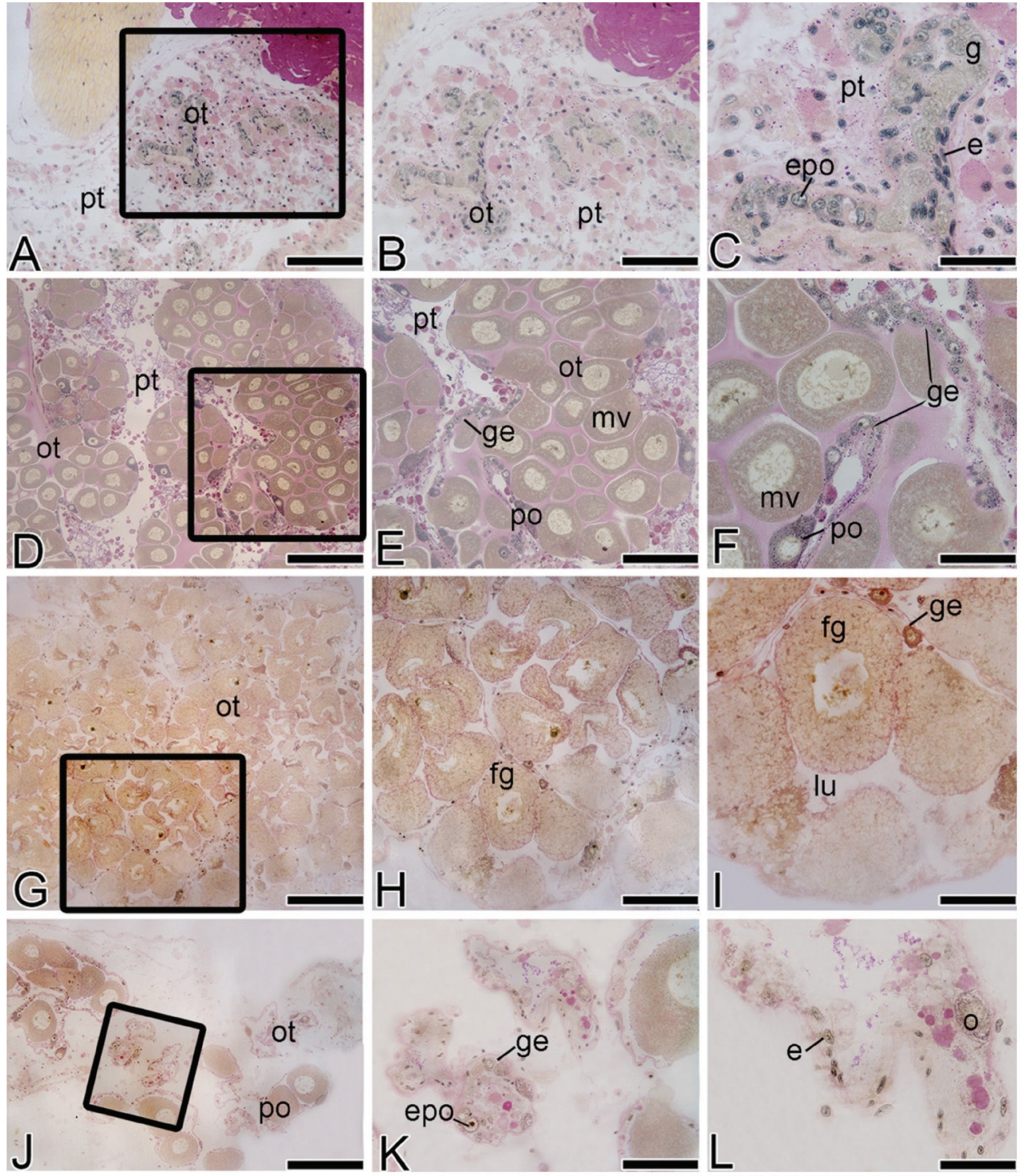

Fig. 6. Microscopic features of a longitudinal section of an ovary of the golden mussel L. fortunei. (Light Microscopy, Periodic-acid Schiff (PAS)/Hematoxylin/Metanil Yellow). (A-B) General view of an ovary in the regenerating phase displays pallial tissue and ovarian tubules. (C) Details showing oogonium, pallial tissue, epithelial cells and early prophasic oocytes. (D-E) General view of the part of the ovary in development showing oocytes, pallial tissue, ovarian tubules, germinal epithelium, previtellogenic oocytes and middle vitellogenic oocytes. (F) Developing phase: detail showing the germinal epithelium, with cell nests and oocytes in different steps of development, previtellogenic oocytes and middle vitellogenic oocytes. (G-H) General view of the ovarian tubules in spawning capable phase showing full-grown oocytes dominant, lumen and germinal epithelium. (I) Spawning capable phase: detailed view of a tubule with full-grown oocytes with yolk globules in the ooplasm, germinal epithelium and lumen. (J-K) General view of the ovary in the regressing phase, showing tubules partially empty, previtellogenic oocytes, ovarian tubules, germinal epithelium and early prophase oocytes. (L) Detail of a tubule with atretic oocyte, epithelial cells and oocyte. e, epithelial cells; epo, early prophasic oocytes; fg, full-grown; g, oogonia, ge, germinal epithelium; lu, lumen; mv, middle vitellogenic oocytes; o, oocyte; ot, ovarian tubules; po, previtellogenic oocytes; pt, pallial tissue. Scale bars: $\mathbf{A}, \mathbf{E}, \mathbf{H}, \mathbf{J}=50 \mu \mathrm{m} ; \mathbf{B}, \mathbf{F}, \mathbf{I}, \mathbf{K}=20 \mu \mathrm{m} ; \mathbf{C}=10 \mu \mathrm{m} ; \mathbf{D}, \mathbf{G}=100 \mu \mathrm{m}$; $\mathbf{L}=15 \mu \mathrm{m}$. 


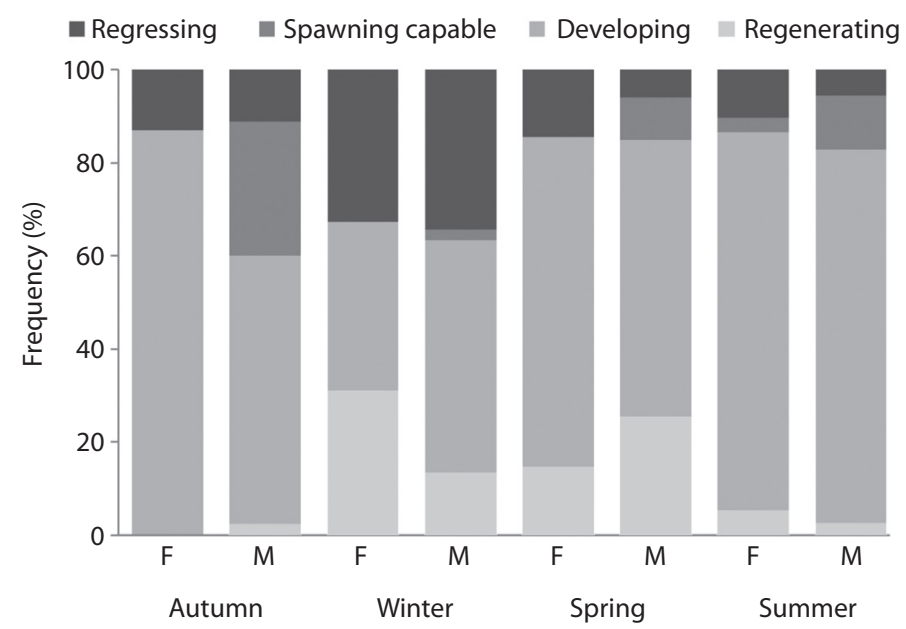

Fig. 7. Frequency of different reproductive phases for females (F) and males (M) according to the season of the golden mussel L. fortunei.

on the author (Darrigran \& Damborenea, 2006; Callil, Gomes, \& Soares, 2012; Boltovskoy et al., 2015).

Most authors (Boltovskoy et al., 2015 for review) consider the initial stage of the reproductive cycle as inactive or resting. However, in this stage there is intense cell proliferation and restocking of the gonad. Thus, the stage or phase previously called "inactive" becomes "regenerating" in this study. Herein, we proposed new terminology based on the dynamic of the germinal epithelium, to recognize phases over the reproductive cycle of $L$. fortunei, i.e. Developing, Spawning Capable, Regressing and Regenerating.

The characterization of the reproductive phases in the female $L$. fortunei takes into account the presence and predominance (in the gonad) of: oogonial proliferation and entrance into meiosis; morphological changes in the ooplasm of the oocytes from the previtellogenic to vitellogenic stages; full-grown to mature oocytes and the spawning event. As regards the males, the characterization of the reproductive phases takes into account the presence and predominance (in the gonad) of: spermatogonial proliferation and entrance into meiosis; differentiation of the gametic cells from spermatids to spermatozoa; and the release and presence of sperm in the gonoduct.
When analyzing the distribution of the reproductive phases of individuals by seasons, L. fortunei was observed to reproduce throughout the year. This is based on the presence of individuals belonging to the regressing phase in the four seasons. This means that they were actively spawning. These data on the life history, herein shown, are similar to studies on the reproductive cycle conducted on other species of mussels (Çek \& Sereflisan, 2006), including the golden mussel (Callil, Gomes, \& Soares, 2012).

Despite that other studies showed that the golden mussel may have one to five spawning periods throughout the year (Callil, Gomes, \& Soares, 2012), depending on the geographical area inhabited, Morton (1982) has stated that it is quite difficult to establish a pattern of spawning for opportunistic species, including L. fortunei, which may have various reproductive strategies, in order to occupy new environments. This opportunistic species spawns throughout the year (Darrigran, Penchaszadeh, \& Damborenea, 1999).

The morphological data and reproductive parameters shown here confirm how informative the cellular dynamic of the germinal epithelium is for the understanding of the cyclic gonadal events during the adult reproductive life of the mollusk in general. This knowledge 
about the gametogenesis and reproductive cycle of invasive or opportunist species (e.g. Limnoperna fortunei) can become a fundamental tool for the development of control strategies and implementation of programs to decrease their proliferation in natural environments (Darrigran \& Damborenea, 2006). Therefore, the data presented herein can contribute to new knowledge about the life history of the golden mussel.

\section{ACKNOWLEDGMENTS}

We thank the following: John J. Stanley $\mathrm{Jr}$ for the grammatical review; Angelo A. Agostinho (PELD-Sítio 6/CNPq) and the Center for Research in Limnology, Ichthyology and Aquaculture-Nupélia Universidade Estadual de Maringá-UEM for financial and logistical support; Alice M. Takeda (Nupélia/DBI/UEM) for the opportunity to work with the golden mussel; Laboratório de Bentos/Nupélia; Laboratório de Patologia - HU/UEM; and Departamento de Morfologia - IBB - UNESP.

\section{RESUMEN}

El mejillón dorado Limnoperna fortunei (Dunker, 1857) es una especie invasora que se ha dispersado rápidamente $\mathrm{y}$ ha colonizado diferentes hábitats potenciales distribuidos por todo el mundo, causando impactos ambientales y económicos. El control de esta especie depende del conocimiento de los aspectos reproductivos. Entre marzo 2010 y diciembre 2012 fueron muestreados periodicamente alrededor de 1200 especímenes de $L$. fortunei en la planicie de inundación del Alto Rio Paraná, Brasil. Con el fin de contribuir con una mejor comprensión de los aspectos reproductivos de L. fortunei, se describió la dinámica celular del epitelio germinativo masculino y femenino durante la vida reproductiva anual de esta especie, mediante histología de alta resolución basada en la actividad del epitelio germinal y el consecuente desarrollo de las células germinales. En este estudio se reconocieron las siguientes fases reproductivas: desarrollo, capacidad de desove, regresión y regeneración. En los machos se describieron las siguientes células germinales: espermatogonias, espermatocitos primarios y secundarios, espermátidas y espermatozoides. Mientras que en las hembras se estudiaron: nidos celulares, ovogonias, ovocitos profásicos tempranos, ovocitos pre-vitelogénicos y ovocitos vitelogénicos (ovocitos vitelogénicos tempranos, ovocitos vitelogénicos y ovocitos completamente desarrollados).
Los datos morfológicos y parámetros reproductivos que se muestran aquí confirman cómo la dinámica celular del epitelio germinal permite la comprensión de los acontecimientos cíclicos gonadales durante la vida reproductiva de adultos del molusco, en general. El conocimiento de la gametogénesis de esta especie invasora puede convertirse en una herramienta fundamental para el desarrollo de estrategias de control y aplicación de programas para disminuir su proliferación en ambientes naturales.

Palabras clave: Bivalvia, Mytilidae, ovogénesis, espermatogénesis, ovario, testículo, Limnoperna fortunei.

\section{REFERENCES}

Alberts, B., Johnson, A., Lewis, J, Raff, M., Roberts, K., \& Walter, P. (2008). Molecular biology of the cell $\left(5^{\text {th }}\right.$ ed). New York: Garland Science.

Boltovskoy, D., Sylvester, F., Otaegui, A., Leites, V., \& Cataldo, D. H. (2009). Environmental modulation of reproductive activity of the invasive mussel Limnoperna fortunei: implications for antifouling strategies. Austral Ecology, 34(7), 719-730.

Boltovskoy, D., Morton, B., Correa, N., Cataldo, D., Damborenea, C., Penchaszadeh, P. E., \& Sylvester, F. (2015). Reproductive output and seasonality of Limnoperna fortunei. In D. Boltovskoy (Ed.), Limnoperna Fortunei: The Ecology, Distribution and Control of a Swiftly Spreading Invasive Fouling Mussel (pp.77-103). Switzerland: Springer.

Boltovskoy, D., \& Correa, N. (2015). Ecosystem impacts of the invasive bivalve Limnoperna fortunei (golden mussel) in South America. Hydrobiologia, 746, 81-95.

Brugnoli, E., Clemente, J., Boccardi, L., Borthagaray, A., \& Scarabino, F. (2005) Golden mussel Limnoperna fortunei (Bivalvia: Mytilidae) distribution in the main hydrographical basins of Uruguay: update and predictions. Anais da Academia Brasileira de Ciências, 77(2), 235-244.

Callil, C. T., Gomes, A. L. T., \& Soares, A. C. P. V. (2012). A gametogênese em Limnoperna fortunei (Dunker, 1857). In M. C. D. Mansur, C. P. Santos, D. Pereira, I. C. P. Paz, M. L. L. Zurita, M. T. R. Rodriguez, M. V. Nehrke, \& P. E. A. Bergonci (Eds.), Moluscos límnicos invasores no Brasil: biologia, prevenção e controle (pp. 111-118). Porto Alegre: Redes Editora.

Campos, M. C. S., Andrade, A. F. A., Kunzmann, B., Galvão, D. D., Silva, F. A., Cardoso, A. V., Carvalho, M. D., \& Mota, H. R. (2014). Modelling of the potential distribution of Limnoperna fortunei (Dunker, 1857) on a global scale. Aquatic Invasions, 9, 253-265.

Çek, S., \& Sereflisan, H. (2006). Certain reproductive characteristics of the freshwater mussel Unio terminalis 
delicates (Lea, 1863) in Golbasi Lake, Turkey. Aquaculture Research, 37, 1305-1315.

Damborenea, C., \& Penchaszadeh, P. E. (2006). Biología reproductiva de Limnoperna fortunei. In G. Darrigran \& M. C. Damborenea (Eds.), Bio-invasión del mejillón dorado en el continente americano (pp. 71-84). La Plata: Edulp.

Darrigran, G. A., Damborenea, M. C., \& Penchaszadeh, P. E. (1998). A case of hermaphroditism in the freshwater invading bivalve Limnoperna fortunei (Dunker, 1857) (Mytilidae) from Rio de la Plata, Argentina. Iberus, 16(2), 99-104.

Darrigran, G., Penchaszadeh, P., \& Damborenea, M. C. (1999). The reproductive cycle of Limnoperna fortunei (Dunker, 1857) (Mytilidae) from a Neotropical temperate locality. Journal of Shellfish Research, 18, 361-365.

Darrigran, G., Penhaszadeh, P., \& Damborenea, M. C. (2000). An invasion tale: Limnoperna fortunei (Dunker, 1857) (Mytilidae) in the Neotropics. In R. Claudi (Ed.), Proceedings $10^{\text {th }}$ International Aquatic Nuisance Species and Zebra-Mussels Conference (pp. 219-224). Toronto, Canada.

Darrigran, G. (2002). Potential impact of filter-feeding invaders on temperate inland freshwater environments. Biological Invasions, 4, 145-156.

Darrigran, G., Damborenea, C., Penchaszadeh, P., \& Taraborelli, C. (2003). Adjustments of Limnoperna fortunei (Bivalvia: Mytilidae) after ten years of invasion in the Americas. Journal of Shellfish Research, 22, 141-146.

Darrigran, G., \& Damborenea, C. (2006). Característica de la espécies. In G. Darrigran \& M. C. Damborenea (Eds.), Bio-invasión del mejillón dorado en el continente americano (pp. 55-70). La Plata: Edulp.

Franco, A., Heude-Berthelin, C., Goux, D., Sourdaine, P., \& Mathieu, M. (2008). Fine structure of the early stages of spermatogenesis in the Pacific oyster, Crassostrea gigas (Mollusca, Bivalvia). Tissue Cell, 40, 251-260.

Franco, A., Jouaux, A., Mathieu, M., Sourdaine, P., Lelong, C., Kellner, K., \& Berthelin, C. H. (2010). Proliferating cell nuclear antigen in gonad and associated storage tissue of the Pacific oyster Crassostrea gigas: seasonal immunodetection and expression in laser microdissected tissues. Cell and Tissue Research, $340,201-210$.

Franco, A., Kellner, K., Goux, D., Mathieu, M., \& Heude-Berthelin, C. (2011). Intragonadal somatic cells (ISCs) in the male oyster Crassostrea gigas: morphology and contribution in germinal epithelium structure. Micron, 42, 718-725.
Garton, D. W., \& Haag, W. R. (1993). Seasonal reproductive cycles and settlement patterns of Dreissena polymorpha in Western Lake Erie. In T. F. Nalepa, \& D. Schloesser (Eds.), Zebra Mussels: Biology, Impacts, and Control (pp. 111-128). Boca Raton: CRC Press.

Lubert, P. (1959). Recherches sur le cycle sexuel et l'emission des gametes chez les Mytilides et les Pectinides (Mollusques, Bivalves). Revue des Travaux de l'Institut des Peches Maritimes, 23, 389-549.

Mello, M. L., \& Vidal, B. C. (1980). Práticas de Biologia Celular. São Paulo: Edgard Blucher.

Morton, B. (1973). Some aspects of the biology and functional morphology of the organs of feeding and digestion of Limnoperna fortunei (Dunker) (Bivalvia: Mytilacea). Malacologia, 12, 265-281.

Morton, B. (1977). The population dynamics of Limnoperna fortunei (Dunker 1857) (Bivalvia: Mytilacea) in Plover Cove Reservoir, Hong Kong. Malacologia, $16,165-182$.

Morton, B. (1982). The reproductive cycle in Limnoperna fortunei (Dunker, 1857) Bivalvia: Mytilidae) fouling Hong Kong's raw water supply system. Oceanologia et Limnologia Sinica, 13, 319-325.

Oliveira, M. D., Calheiros, D. F., Jacobi, C. M., \& Hamilton, S. K. (2011). Abiotic factors controlling the establishment and abundance of the invasive golden mussel Limnoperna fortunei. Biological Invasions, 13, 717-729.

Oliveira, M. D. de, Ayroza, D. M. R., Castellani, D., Campos, M. de C. S., \& Mansur, M. C. D. (2014). O mexilhão dourado nos tanques-rede das pisciculturas das regiões Sudeste e Centro-Oeste. Panorama da Aquicultura, 24(145), 22-29.

Pipe, R. K. (1987). Ultrastructural and cytochemical study on interactions between nutrient storage cells and gametogenesis in the mussel Mytilus edulis. Marine Biology, 96, 519-528.

Puchtler, H., \& Waldrop, F. W. (1978). Silver impregnation methods for reticulum fibers and reticulin: A reinvestigation of their origins and specificity. Histochemistry, 57, 177-187.

Quintero-Hunter, I., Grier, H., \& Muscato, M. (1991). Enhancement of histological detail using metanil yellow as counter stain in Periodic Acid Schiff's hematoxylin staining of glycol methacrylate tissue sections. Biotechnic and Histochemistry, 66, 169-172.

Santos, S. B., Thiengo, S. C., Fernandez, M. A., Miyahira, I. C., Gonçalves, I. C. B., Ximenes, R. de F., Mansur, M. C. D., \& Pereira, D. (2012). Espécies de moluscos límnicos invasores no Brasil. In M. C. D. Mansur, C. P. Santos, D. Pereira, I. C. P. Paz, M. L. L. Zurita, M. 
T. R. Rodriguez, M. V. Nehrke, \& P. E. A. Bergonci (Eds.), Moluscos límnicos invasores no Brasil: biologia, prevenção e controle (pp. 25-49). Porto Alegre: Redes Editora.

Saucedo, P., \& Southgate, P. C. (2008). Reproduction, Development and Growth. In P. C. Southgate, \& J. S. Luca (Eds.), The pear oyster (pp. 131-185). Amsterdam, Elsevier.

Shafee, M. S. (1989). Reproduction of Perna picta (Mollusca: Bivalvia) from the Atlantic coast of Marocco. Marine Ecology Progress Series, 53, 235-245.

Soot-Ryen, T. (1955). A report on the family Mytilidae (Pelecypoda). Allan Hancock Pacific Expeditions, 20(1), 1-175.
Takeda, A. M., Fujita, D. S., \& Fontes-Junior, H. M. (2007). Bivalves invasores no rio Paraná. In S. B. Santos, A. D. Pimenta, S. C. Thiengo, M. A. Fernandez, \& R. S. Absalão (Eds), Tópicos em Malacologia (pp. 81-86). Rio de Janeiro: Ecos do XVIII Encontro Brasileiro de Malacologia.

Vidal, B. C. (1987). Métodos em Biologia Celular. In B. C. Vidal, \& M. L. Mello (Eds.), Biologia Celular (pp. 485-494). Rio de Janeiro: Atheneu.

Vidal, B. C. (1988). Histochemical and anisotropical properties characteristics of silver impregnation: the differentiation of reticulin fibers from the other interstitial collagens. Zoologisches Jahrbuch für Anatomie, 117, 485-494. 